\title{
Düalist Zihin Felsefesi Bağlamında Kavramsal Sanat Kavrayışını Anlamaya Yönelik Bir Araştırma
}

\author{
A Research to Understand Conception of Conceptual Art in the Context of Dualist Philosophy of Mind \\ Tayfun Akdemir, Sanat ve Tasarım Anasanat Dalı, Çukurova Üniversitesi
}

\section{Özet}

$\mathrm{Bu}$ çalıșma, düalist zihin felsefesi bağlamında kavramsal sanat kavrayışını anlamaya yönelik bir araştırmadır. Çalışmanın amacı kavramsal sanat kavrayışının içerisinde örtük olarak bulunduğu iddia edilen düalist dünya varsayımını aydınlatmaktır. Kavramsal sanat ile birlikte gündeme gelen sanatın zihinsel bir etkinlik olduğu iddiası, düalist zihin felsefesi çerçevesinden bakıldığında sanatın duyulur dünyaya indirgenemez bir gerçeklik olduğu varsayımını tașımaktadır. Çünkü düalist zihin felsefesi içerisinde zihinsellik ve fiziksellik birbirlerinden ayrı gerçeklikler olarak kabul edilmektedir. Zihinsellik, maddi gerçekliğin bir ürünü olarak değil, insanın akıllı ruh ile yaratılmıș olmasının bir göstergesi sayılmaktadır; beden de dahil olmak üzere fiziksel dünya evrenin yasalarına bağlı maddesel bir gerçeklik olarak tasarlanmaktadır. Sanatın zihinsel bir etkinlik olarak kabul edilmesi ve düşünsel süreçlerin sanat yüklemi taşıdığı düşüncesi, düalist zihin felsefesi bağlamında sanatın herhangi bir fiziksellik içermeden, salt zihinsel bir etkinlik olarak gerçekleştirilebileceği ve bunun sanatın varlığı için yeter kabul edilebileceği olasılığını doğurur. Bu türden bir olasılıkta, herkes tarafından algılanabilir, fiziksel gerçekliğe dayalı bir sanatın varlığından söz etmek olanaksız görünmektedir. Sonuç olarak, düalist zihin felsefesi çerçevesinden bakıldığında kavramsal sanat kavrayışı öznel gerçekliğe dayalı bir sanat kavrayıșı olarak yorumlanabilir; kavramsal sanat içerisinde zihinselliğin dayanak alınması ile birlikte fiziksellik sanatın koşulları dışına itilmektedir.

Anahtar Sözcükler: Sanat, kavramsal sanat, zihinsellik, fiziksellik, düalizm.

Akademik disipin(ler)/alan(lar): Felsefe, zihin felsefesi, sanat, sanat felsefesi.

\begin{abstract}
This study is a research to understand conception of conceptual art in the context of dualist philosophy of mind. The main purpose of this study is to analyze the hypothesis of dualist world that is implicitly present in the conception of conceptual art. The claim that art is an intellectual activity which emerges with the conceptual art assumes that, through the perspective of dualist philosophy of mind, art is a reality that is irreducible to the material world. Because, in the dualist philosophy of mind, intellectuality and physicality are assumed to be separate realities. Intellectuality is not regarded as the product of physical reality, but as a result of humans being created with an intelligent spirit; the physical world including the body is designed as material reality that is bound to the laws of the universe. Acceptance of art as an intellectual activity and the idea that intellectual prosesses carry art value, raises the possibility that art can be realized as a pure intellectual activity that does not have and physicality and it can exist as an intellectual activity only in the context of dualist philosophy of mind. In this possibility, it seems impossible to talk about the existence of art in the physical world that can be percevied by everyone. As a result, in the context of the dualist philosophy of mind, conception of conceptual art can be interpreted as an art that is based on subjective reality; with the reference of mentality in art phyciality is pushed out of the conditions of art.
\end{abstract}

Keywords: Art, conceptual art, intellectuality, physicality, dualism.

Academical disciplines/fields: Philosophy, philosophy of mind, art, philosophy of art.

- $\quad$ Sorumlu Yazar: Tayfun Akdemir, Cukurova Üniversitesi, Sosyal Bilimler Enstitüsü, Sanat ve Tasarım Anasanat Dalı

- $\quad$ Adres: Çukurova Üniversitesi, Eğitim Fakültesi, Güzel Sanatlar Eğitimi Bölümü, 01330 Balcalı, Sarıçam-Adana

- $\quad$ e-posta: akdemirtayfun@gmail.com

- ORCID: 0000-0002-9301-5425

- Cevrimiçi yayın tarihi: 18.05 .2020

- doi: $10.17484 /$ yedi. 689179 


\section{Giriș}

$\mathrm{Bu}$ çalıșma, düalist zihin felsefesi bağlamında kavramsal sanat kavrayıșını anlamaya yönelik bir araştırmadır. Çalışma, kavramsal sanat kavrayışının düalist dünya görüşüne dayandığı varsayımından yola çıkmaktadır. Bu varsayım, en genelde Sol LeWitt'in kavramsal sanatı tanımladı̆̆ Kavramsal Sanat Üzerine Paragraflar (Paragraphs on Conceptual Art) ve Kavramsal Sanat Üzerine Tümceler (Sentences on Conceptual Art) bașlıklı metinlerine dayanmaktadır. Bu metinler, temel olarak, sanatın zihinsel bir etkinlik olduğu düşüncesi üzerine yapılanmaktadır. Çalışmanın amacı sanatın zihinselliği düşüncesinin tam olarak ne anlama geldiğini anlamak ve kavramsal sanat kavrayışı içerisinde örtük olarak bulunduğu iddia edilen düalist dünya görüşünü aydınlatmaktır. Çalışma, Giriş ve Sonuç başlıkları hariç iki alt başlıktan oluşmaktadır. İlk alt bașlık altında kavramsal sanatın hangi bağlamda düalist zihin felsefesi ile ilişkilendirilebileceği belirtilmekte ve kavramsal sanatın yapısında örtük olarak bulunduğu iddia edilen düalist dünya görüşü çözümlenmektedir. İkinci alt başlık altında ise sanatın zihinselliği düşüncesinin tam olarak ne anlama geldiği zihinsellik ile fiziksellik arasında olduğu düşünülen ayrım bağlamında çözümlenmektedir.

\section{Düalist Bir Dünya Varsayımı Olarak Kavramsal Sanat}

Kavramsal sanat, tarihsel olarak, Sol LeWitt'in 1967'de Art Forum'da yayımlanan Kavramsal Sanat Üzerine Paragraflar başlıklı metni ile başlatılabilir (Akdemir ve Köse, 2018, s.325). Bu metnin kavramsal sanatın başlangıcı olarak kabul edilmesinin temel gerekçesi, kavramsal sanat düşüncesinin ilk defa bu metinde sistematik olarak işlenmesidir. İlgili metinde kavramsal sanat, sanatın zihinsel olduğu ilkesi üzerine inșa edilmektedir; kavramsal sanatta düşünü sanat yapıtının en önemli yanı olarak kabul edilmektedir (LeWitt, 1980a, s.19). Sol LeWitt, Kavramsal Sanat Üzerine Paragraflar bașlıklı metninde, genel olarak, kavramsal süreçler ile fiziksel gerçeklik arasında bir ayrım yapmaktadır. Sol LeWitt'in ifade ettiğine göre sanat yapıtı kavramsal bir süreçtir; bu nedenle sanatçı ilk olarak kavramsal süreçler ile ilgilenir; ikinci olarak ise kavramsal süreçlerin fiziksel bir gerçekliğe kavuşturulması gerekir (LeWitt, 1980a, s.19). Kavramsal sanatın düalist dünya görüşüne temellendiği Sol LeWitt'in ortaya koyduğu bu modelde örtük olarak içerilmektedir. İlgili modelde kavramsal süreçler fiziksel gerçeklikten ayrı tutulmaktadır. Kavramsal süreçler fiziksel gerçekliğe kavuşturulması gereken gerçeklikler olarak belirtilmektedir. Dolayısıyla kavramsal süreçler fiziksel olmayan gerçeklikler olarak kabul edilmektedir. Sol LeWitt, zihinsellik ve fiziksellik arasında olduğu varsayılan ayrımı önsel olarak kabul etmekte ve kavramsal sanatı bu ayrım üzerine inșa etmektedir. Kavramsal sanatın düalist zihin felsefesi ile olan ilișkisi, ilkesel olarak, kavramsal süreçlerin fiziksel gerçeklikten ayrı tutulmasına dayanmaktadır. Kavramsal süreçlerin fiziksel gerçeklikten ayrı tutulduğu bir düşünce sistemi doğası gereği düalist bir düşünce sistemidir (Günday, 2002, s.37). Düalist düşünce sistemleri içerisinde kavramsal süreçler zihinsel etkinlikler olması bakımından fiziksel olmayan süreçler olarak kabul edilmektedir. Çünkü düalist zihin felsefesinin özü zihnin özsel doğasının fiziksel olmayan bir töze veya niteliğe dayandığı düşüncesine temellenmektedir (Churchland, 2012, s.12). Düalist zihin felsefesi içerisinde zihinsel durum ve süreçler fiziksel durum ve süreçlerden ontolojik açıdan ayrı düşünülmektedir. Zihinsellik ve fiziksellik arasında olduğu kabul edilen bu ayrım, insanın zihin ve beden olmak üzere ikiye ayrılması ile doğrudan ilișkilidir. Düalist zihin felsefesinin kurucu filozofu olarak anılan Descartes, Meditasyonlar- Metafizik Üzerine Düșünceler bașlıklı çalıșmasının altıncı bölümünde, insanın, zihin ve beden olmak üzere, iki öğeden oluştuğunu ifade etmektedir (Descartes, 2019a, s.124). Descartes'a göre zihin ve beden arasındaki temel fark bedenin doğası gereği sonsuza bölünebileceği, buna karşılık zihnin hiçbir șekilde bölünemeyeceği düșüncesi ile ilișkilidir. Descartes, düşünen bir varlık olarak kendisini göz önüne aldığında, isteme, anlama ve duyularla algılama gibi yetilerde dahil olmak üzere, içsel herhangi bir parçasının, diğer bir deyişle zihinsel durum ve süreçlerinin parçalara ayrılamayacağını belirtmektedir (Descartes, 2019a, s.120). Çünkü Descartes'a göre isteyen, anlayan ve duyularla algılayan bir ve aynı zihindir. Buna karşılık beden göz önüne alındığında, eller, ayaklar veya bedenin diğer uzuvları eksilebilir. Bu eksilme bedenin beden olmak bakımından bütünlüğünü etkilememektedir. Ona göre yalnızca bedenin bir parçası eksilmektedir. Dolayısıyla beden maddi bir varlık olmak bakımından doğası gereği parçalı ve bölünebilirdir (Descartes, 2019a, s.121). Fakat zihni bölmek ve bu bölümleri zihnin varlığından ayrı düşünmek olanaksızdır.

Sol LeWitt'in kavramsal süreçler ile fiziksel gerçeklik arasında yaptığı ayrım, Descartes'ın zihne ait süreçler ile bedene ait süreçler arasında yaptığı ayrım ile benzerlikler taşımaktadır. Descartes, zihni ve zihinsel süreçleri, bedenden ve bedenin ait olduğu fiziksel dünyadan ontolojik olarak ayırmaktadır. Ona göre bedeni düşünen bir şey olarak hayal etmek olanaksızdır; sahip olduğumuz her türlü düşünce ruha ait olmalıdır (Descartes, 2015, s.25). Sol LeWitt'e ait sanatın kavramsal süreçler ile ilgili olduğu iddiası, Descartes'ın 
zihne ait süreçler ile bedene ait süreçler arasında yaptığı ayrım bağlamında değerlendirildiğinde sanatın fizik dünyaya indirgenemez bir gerçeklik olduğu varsayımını taşımaktadır. Bu varsayıma şu akıl yürütme ile ulaşılmaktadır: (1) sanat, kavramsal süreçler ile ilgilidir; (2) kavramsal süreçler zihinseldir; (3) zihinsel olan şeyler fiziksel değildir; (4) o halde sanat etkinliği fiziksel değildir. Sanat etkinliği fiziksel değildir derken sanatın fiziksel olaylar üzerinden açıklanamayacağı kast edilmektedir. Sanatın zihinsel bir etkinlik olduğu iddiası ile birlikte fiziksellik sanatın koşulları dışına itilmektedir. Sanatın zihinsel bir etkinlik olduğu iddiası ve zihinsellik ile ilişkili olarak fizikselliğin dışarıda bırakılması, varlığın zihinsel ve fiziksel olmak üzere ikiye bölündüğü bir düşünce sistemini gerektirmektedir. Zihinsel varlıkların var olduğu ve bu varlıkların gayri maddi varlıklar olduğu varsayımı düalist ontolojiye temellenmektedir. Düalist ontoloji veya ontolojik düalizm, Descartes'ın ortaya koyduğu zihin felsefesi ile bağlantılıdır fakat en genel anlamıyla Aristoteles'in varlık sınıflandırmasına dayanır. Aristoteles'in varlık sınıflandırması, doğrudan düalist ontoloji olarak anılmasa da duyusal (maddi) ve düşünsel (gayri maddi) varlıkların birbirlerinden farklı türde varlıklar olduğu düşüncesini barındırmaktadır. Aristoteles'e göre duyusal varlıklar devinen, oluş ve yok oluşa tabi somut bileşik varlıklardır; düşünsel varlıklar ise devinimsiz, öncesiz ve sonrasız soyut nitelikte varlıklardır (Özcan, 2009, s.119). Düşünsel varlıklar, duyusal varlıklardan soyutlamayla elde edilen varlıklardır; bu varlıklar ya duyusal varlıklardan soyutlamayla elde edinilirler ya da sirf düşüncenin ürünüdürler (Özcan, 2009, s.119). Sanatın fiziksellikten arındırılması, yani sanatta zihinselliğin referans alınması, yapısal olarak düşünsel anlamda var olanlara, dolayısıyla gayri maddi varlıklara dayalı bir etkinliği gerektirmektedir. Bu da kavramsal sanatın düalist ontoloji üzerine kurulu bir sanat yaklaşımı olduğunu gündeme getirmektedir. Özellikle Lucy Lippard'ın şu ifadesi, kavramsal sanatın, gerçekliğin duyusal (maddi) ve düşünsel (gayri maddi) olmak üzere ikiye ayrıldığı bir kavrayış üzerinden ilerlediğini düşündürmektedir. "Kavramsal sanat, benim için, fikrin esas olduğu, malzemenin ise ikincil, hafif ve/veya 'geçici' olduğu bir eseri anlatır." (Lippard, 1997, vii). Lucy Lippard kavramsal sanatta fikrin temel olduğunu, malzemenin ise fikirden ayrı olarak, geçici ve ikincil bir öğe olduğunu aktarmaktadır. Dolayısıyla Lucy Lippard, kavramsal sanat adı verilen sanat yaklaşımının fikir üzerine kurulu olduğunu savunmaktadır. Lucy Lippard'ın burada 'malzeme' ile kastettiği şeyin maddesel olan, diğer bir deyişle cismi olan şey olduğu açlktır; 'fikir'i ise geçiciliğin bir karşıtı olarak kullanmakla beraber, sanatın temellendiği esas gerçeklik olarak varsaymaktadır. Lucy Lippard'ın fikir ile malzeme arasında yaptığı ayrım düalist ontoloji içerisinde maddi ve gayri maddi varlıklar arasında yapılan ayrım ile bağlantılıdır. Fikir, düşünsel bir varlık olmak bakımından öncesiz, sonrasız ve kalıcı bir varlık türü olarak kabul edilirken; malzeme, duyusal bir varlık olmak bakımından geçici, oluş ve yok oluşa tabi varlık türü olarak kabul edilmektedir. Bu bağlam ile ilişkili olarak Arthur Danto şöyle bir örnek vermektedir:

(...) bir şiirin basılı olduğu bir kitabın bir kopyasını yakabilirim, ancak bunu yaparak şiiri yakmış olmam zira sayfa zarar görmüştür şiir değil. Başka bir kopyanın içinde var olmayı sürdürmesine karşın farklı bir kopyanın içindeki şiir ile basılı olduğu sayfanın yakıldığı şiir basitçe özdeş olamaz. (Danto, 2012, s.53)

Arthur Danto, bir şiirin varlığının özsel olarak kitap sayfasına dayandırılamayacağını ifade etmektedir. Bu düşünce bizi doğallıkla Platonik formlar ve onların kopyaları arasındaki ilişkiyi düşündürmektedir; Arthur Danto'ya göre kopyalar zarar görse de form etkilenmeden kalır çünkü form edebi olandır (Danto, 2012, s.53). Kavramsal dünyadaki şiir, diğer bir deyişle form olan şiir farklı yöntemler ile kendini temsil edebilecek birçok farklı malzemeye eşlenebilir, zamanla çoğaltılabilir veya eşlendiği tüm malzemeler yok edilebilir. Fakat malzemelere uygulanan tüm bu fiziksel etkiler, düşünsel süreçleri beyin süreçlerine indirgeyen bir kuram önsel olarak kabul edilmediği sürece fikrin kendisini herhangi bir biçimde etkilemeyecektir. Aristoteles'in sınıflandırdığı gibi düşünsel varlıklar oluş ve yok oluşa tabi varlıklar değildir.

Lucy Lippard'ın malzeme ile fikir arasında yaptığı ayrım, zihin felsefesi çerçevesinden bakıldığında zihinsel durumlar ile fiziksel durumlar arasında yapılan ayrım ile paralellikler tașımaktadır. Lucy Lippard, malzeme ve fikir hakkındaki düşüncelerini ifade ederken örtük olarak zihinsel durumların tekliği, öznelliği ve kalıcılığı ile fiziksel durumların çokluğu, kamusallığı ve geçiciliğini karşılaştırmaktadır. Bu karşılaştırmanın belli bir ölçüde monist kuramlara dayandırılamayacağı iddia edilebilir. Bazı monist kuramlar evrenin temelde fiziksel bir varoluşu olduğu söyler ve maddesel olmayan bir gerçekliği reddeder. Bu, zihinlerin varoluşu içinde geçerlidir. Örneğin indirgemeci maddecilik, zihinsel durum ve süreçleri beyin durum ve süreçlerine indirgemektedir. Yani zihinsel etkinlikler maddi olmayan bir doğaya ait değildir; indirgemeci maddecilikte düşünme de dahil olmak üzere, Descartes tarafından akıllı ruha ait kılınan tüm zihinsel etkinlikler nörofizyolojik nedenler ile açıklanmaktadır. Buna ek olarak elemeci maddecilik ise zihin veya ruh gibi kavramları bilimden, zihin felsefesi bağlamında ise felsefeden dışlayan bir yaklaşımdır (Revonsuo, 2017, s.55). Yani elemeci maddecilikte doğrudan zihinlerin varlığı reddedilmektedir. Elemeci maddeciler, 
zihinlerin veya ruhların var olduğuna dair geliștirilen kuramların oldukça zayıf olduğunu savunmaktadır. Onlara göre bu kuramlar, yeterli bilimsel kanıtları veya mantıksal çıkarımları içermediği için bilimsel veya felsefi bir kuramdan ziyade daha çok bir halk psikolojisidir. Dolayısıyla hem indirgemeci maddecilik içerisinde hem de elemeci maddecilik içerisinde maddesiz bir varlığın var olabileceği olasılığı içerilmemektedir. Buna karşılık bazı monist kuramlar ise evrenin temelde zihinsel tözden olduğunu savunmaktadır (Revonsuo, 2017, s.36). Bu kuramlarda zihinlerin varlığı esasken, fiziksel şeylerin var olduğuna dair veya fiziksel şeylerin gerçek tözler olduğuna dair bir kanıta inanılmamaktadır. Sonuç olarak, Lucy Lippard'ın fikir ve malzeme arasında yaptığı karşılaştırma ne elemeci maddecilikle ne indirgemeci maddecilikle ne de zihinsel gerçekliği temel alan monizm ile ilişkilendirilebilir. Çünkü monist düşünce sistemleri çoklukları birliğe indirgemeye yönelik öğretilerdir (Hançerlioğlu, 1992, s.179). Bu nedenle fiziksellik ve zihinsellik arasında kurulan karşıtlık her türlü monizm ile çelişmektedir. Lucy Lippard'ın fikir ile malzeme karşılaştırması, zihinsel ve fiziksel varlıkların birbirlerinden ayrı gerçeklikler olarak var olmasını, yani varlığın maddi ve gayri maddi olmak üzere iki ayrı türe veya niteliğe ayrılmasını önsel olarak gerektirmektedir. Dolayısıyla Lucy Lippard'ın kavramsal sanatın yapısıyla ilişkili olarak ortaya koyduğu fikir ile malzeme karşılaştırması ancak düalist zihin felsefesi bağlamında anlamlı bir karşılaştırma olarak yorumlanabilir.

\section{Sanatın Zihinselliği}

Genel olarak kavramsal sanat incelemelerinde ve özellikle Sol LeWitt, Lawrence Weiner ve Joseph Kosuth gibi sanatçların metinlerinde, biçimden ziyade fikir üzerinde durulması ve düșünce olgusunun vurgulanması, sanatın zihinsel bir etkinlik olduğu iddiası ile ilişkilidir. Sol LeWitt, 1969'da Art-Language dergisinde yayımlanan Kavramsal Sanat Üzerine Tümceler başlıklı metninde şu ifadelere yer vermektedir: "Düşünüler sanat yapıtı olabilir. Sonuçta birden biçim bulabilir bir gelişim zinciri içindedirler. Her düşününün maddesel duruma getirilme gereği yoktur." (LeWitt, 1980b, s.23). Sol LeWitt'e ait yalnızca düşünülerin sanat yapıtı olabileceği fikri, düalist zihin felsefesi bağlamında ele alındığında, sanatın bir öznel deneyim gerçekliği olarak kabul edilebileceği sonucuna götürmektedir. Zihinsel süreçlerin öznel deneyim gerçeklikleri olarak kabul edilmesi düalist zihin felsefesi ile ilişkilidir. Düalist zihin felsefesi içerisinde zihnin ve bedenin birbirlerinden ontolojik olarak ayrılması ile zihinsel, diğer bir deyişle içsel tüm etkinlikler ve bedensel, yani çevreden gelen uyaranlara karşı gösterilen tepkiler birbirlerinden ontolojik olarak ayrılmaktadır. Yani düalizm içerisinde zihinsellik ile fiziksellik arasında mutlak bir ayrım yapılmaktadır (Edelman ve Tononi, 2019, s.20). Öyle ki Descartes'ın sisteminde bir şey ya zihinsel dünyaya aittir ya da fiziksel dünyaya; zihinsel süreçler kassal eylemlere indirgenemeyeceği gibi kaslar da zihinsel faaliyet gerçekleştiremez (Descartes, 2019b, s.71). Fakat zihinsel süreçler beden hareketlerine neden olabileceği gibi beden de zihinsel süreçlere neden olabilir. Buna düalist zihin felsefesi içerisinde iki yönlü etkileşimcilik denmektedir. İki yönlü etkileşimcilik modeline göre zihin bedene, beden ise zihne ekti edebilir. Örneğin kitap okuma arzusu gibi zihinsel bir durum kitap okuma etkinliği gibi fiziksel bir olaya neden olabilir. Kitap okuma arzusu zihinseldir ve bu durum kişinin kendisi dışında bir dış gözlemciye açık değildir fakat kitap okuma etkinliği kişinin kendisi de dahil olmak üzere bir dış gözlemci tarafından gözlemlenebilir. Öznel beden algıları da dahil olmak üzere düşünme gibi süreçler kişinin kendisi dışında gözlemlenemeyen süreçler olduğundan Descartes tarafından fiziksel olmayan doğa olayları olarak kabul edilmiştir. Çünkü Descartes, zihinlerin fiziksel nesneler gibi gözlemlenemeyeceğini, zihinsel durum ve süreçlerin ancak kişinin kendisine açık olduğunu, dolayısıyla ağrı, acı, haz ve diğer düşünsel etkinliklerin mahiyetinin ancak kişinin kendisi tarafından bilinebileceğini savunmaktadır. Yani Descartes, zihinsel durum ve süreçleri öznel bir gerçeklik olarak tasarlamaktadır. Genel olarak düalist zihin felsefesi, zihinsel durum ve süreçlerin öznel bir gerçeklik olduğu varsayımı üzerine yapılanmaktadır. Bu bağlamda bir şeyin zihinsel bir etkinlik olduğunu savunmak veya bir şeyi zihinsel süreçler ile ilişkilendirmek o şeyi öznel bir gerçekliğe indirgemek anlamına gelir. Dolayısıyla sanatın zihinsel bir etkinlik olduğu iddiası, öznel gerçekliğe indirgenen bir sanat kavrayışını gündeme getirmektedir. Özellikle Sol LeWitt ve Lawrence Weiner gibi isimler sanatın zihinsel durum ve süreçlere ait olduğuna sık sık değinmektedir. Buna göre sanat yapıtı adı verilen gerçeklik özsel olarak zihinselken, bu yapıtın bir nesne aracılığı ile görünür kılınması meselesi iletişimsel bir gereklilik olarak düşünülmektedir.

Öznel gerçekliğin referans alındı̆̆ı bir sistem içerisinde sanat, kişinin kendisi dışında, zihinsel süreçlerin öznel doğası dolayısıyla dışarıdan bir gözlemci tarafından deneyimlenemeyecektir. Kişinin sanat etkinliği gerçekleştirdiği yine kişinin kendisi tarafından, iç gözlem yoluyla bilinebilir. İç gözlem, genel olarak çeşitli zihin durumlarının farkındalığına dayanan bilinçlilik hali olarak tanımlanmaktadır. Bu türden bilinçlilik halleri farkındalığının farkında olmak anlamında kendinin bilincinde olmak türünden bilinç korelasyonlarıdır (Zeman, 2017, s.49). Kişi, zihinsel dünyasında ne olup bittiğinin, diğer bir deyişle düşünsel 
eyleminin niteliğinin ve içeriğinin bilincinde olduğunda kendisinin bilincinde olarak nitelendirilebilir. Sanatın zihinsel bir etkinlik olarak kabul edilmesi ve sadece düşünülerin sanat yapıtı olabileceği düşüncesi, sanatın herhangi bir fiziksellik içermeden, salt zihinsel olarak gerçekleștirilebileceği ve bunun sanatın varlığı için yeter kabul edilebileceği sonucunu doğurur. Bu türden bir sonuçta, sanatçının kendisi dışında, herkes tarafından algılanabilir, kamusal bir sanatın varlığından söz etmek olanaksız görünmektedir. Şu hâlde, kavramsal sanata ait sanatın zihinsel bir etkinlik olduğu iddiasının sanatı içsel, bu anlamda öznel bir yapıya çektiği ifade edilebilir. Kavramsal sanat ile birlikte gündeme gelen sanatın zihinselliği iddiası düalist zihin felsefesi bağlamında yorumlandığında sanatın nesnelliğini ortadan kaldırmaktadır. Descartes'ın da sınırladığı gibi zihinsel olanı gözlemlenebilir bir olgu olarak ele almak metodolojik olarak olanaksızdır. Zihinsel olanı gözlemlenebilir bir olgu olarak ele almanın olanaksızlığı temel olarak zihinsel durum ve süreçlerin beyin durum ve süreçlerinden tamamen farklı süreçler olmasına dayanmaktadır. Beyin durum ve süreçleri, doğru seçilmiş birkaç araçla gözlemlenebilirken zihinsel durum ve süreçler yalnızca ona sahip olan kişiye açıktır (Zeman, 2017, s.379). Düalist zihin felsefesi bağlamında zihinsel durum ve süreçler, nörofizyolojik nedenlerin ötesine uzanan daha ileri bir olgu durumundan, doğal olarak gayri maddi bir varlıktan kaynaklanmaktadır (Zeman, 2017, s.380). Zihinsel süreçler, algılanan bir nesnenin duyumundan, düşünülen bir kavramdan veya ağrı ve acı gibi öznel beden algılarından meydana gelebilir. Dolayısıyla zihinsel süreçleri meydana getiren içerik sadece dünyada var olan nesneler veya durumlar hakkında olmak zorunda değildir, hakkında düşünülebilen tüm şeyler zihinsel süreçlerin içeriğini meydana getirmektedir. Kavramsal sanat ile birlikte gündeme gelen sanatın zihinsel bir etkinlik olduğu iddiası, bu çerçeveden ele alındığında, sanat etkinliğinin öznel deneyime ait bir gerçeklik olduğunu sonucuna götürmektedir. Çünkü bu türden zihinsel süreçler ki bu süreçlerin fiziksel bir varoluşu olmadığı düşünülmektedir, öznel gerçekliklerdir. Sanatın zihinsel bir etkinlik olduğu iddiası ile birlikte sanat, kendi benliğimizi bulduğumuz öznel deneyim gerçekliğine ve bu gerçekliğin içerisinde çeşitli zihinsel durumların farkındalı̆̆ına indirgenmektedir. Böyle bir sonuca ulaşılmasının temel gerekçesi düalist zihin felsefesi içerisinde zihinselliğin fiziksel gerçeklikten tamamen ayrı bir gerçeklik olarak kabul edilmesi ile ilişkilidir.

Tablo 1. Zihinsel ve fiziksel yüklemler karşıtllğı (Priest, 2018, s.306).

\begin{tabular}{|cc|}
\hline Zihinsel Yüklemler & Fiziksel Yüklemler \\
Zamansal & Uzaysal \\
Mahrem & Kamusal \\
Tashih edilir & Tashih edilmez \\
İçsel & Dışsal \\
Özgür & Belirlenmiş \\
Ben & Başkası \\
Kutsal & Profan \\
Şekilsiz & Şekilli \\
Öznel & Nesnel \\
\hline
\end{tabular}

Stephan Priest'in Zihin Üzerine Teoriler adlı kitabından yer alan bu tablo (burada tabloda yer alan tüm kavramlara yer verilmemiștir) bir şeyin zihinsel ve fiziksel olarak adlandırılmasında örtük olarak ima edilen bazı temel kavramları içermektedir. Stephen Priest bu listeyi, zihin-beden sorununu çözme girişimlerinin içine düştüğü yanlışı göstermek üzere kullanmaktadır. Ona göre bu listedeki bir kavramı, karşıt olduğu kavramlara indirgeme girişimi metodolojik olarak yanlıştır. Çünkü bu kavramlar anlamsal bakımdan birbirlerine indirgenemezdir (Priest, 2018, s.307). Örneğin zihinsel bir durum için uzaysal yüklemler kullanmak veya zihinsel bir durumu kamusal kılmak çelişik bir durum yaratmaktadır. Zihinsel yüklemler ve fiziksel yüklemler arasındaki karşllığı gösteren bu tablo kavramsal sanatta neden fiziksel yüklemlerin referans alınmadığını da açıklığa kavuşturmaktadır. Sanatın zihinsel bir etkinlik olduğu iddiası yapısı gereği fiziksel yüklemleri dışarıda bırakmaktadır. Öyle ki Sol LeWitt'e ait şu ifade bu argümanı desteklemektedir: "Üç boyutlu nesnenin fizikselliği duyusal olmayan içeriğiyle çelişkiye düşer. Renk, doku, yüzey ve biçim ürünün yalnızca fiziksel yanını güçlendirir. Bu fiziksellikte izleyicinin ilgisini çeken herhangi bir şey bizim düşünü alanımıza engeldir ve dışavurumsal bir kurgu olarak kullanılır." (LeWitt, 1980a, s.20). Sol LeWitt burada nesnenin fizikselliği ve duyusal olmayan içeriği arasında bir ayrım yapmakta, duyusal olmayan içeriği 
fizikselliğe karşıt bir öğe olarak konumlandırmaktadır. Sol LeWitt'in nesnenin duyusal olmayan içeriğinden bahsetmesi bizi doğallıkla zihinsel gerçeklikler olan kavramlara götürmektedir. Bertrand Russell, tümelleri fark etmeye kavrama, farkında olduğumuz bir tümele de kavram denir diyor (Russell, 2000, s.49). Yani Bertrand Russell tümel olanı, kavram olarak tanımlıyor. Bu tanıma göre şeylere ait duyusal bilginin belli bir kategori oluşturulacak biçimde soyutlanması tümel olana, yani kavrama ulaştırmaktadır. Burada kavram, diğer bir deyişle tümel olan, nesneye ait bir nitelik olarak değil, nesneler arası bir özellik olarak ele alınmaktadır. Dolayısıyla kavram, doğrudan nesnenin duyumsanabilir bir içeriği değildir, kavramın oluşumu nesneler üzerine zihinsel bir işlemi gerektirmektedir. Sol LeWitt, nesnenin duyusal olmayan içeriği ile büyük olasılıkla tümel olanı, yani kavramı kast etmektedir. Ona göre kavramların zihinselliği nesnelerin fizikselliği ile çelişkiye düşmektedir.

Sol LeWitt'in kavramsal gerçeklik ve nesnelerin fizikselliği arasında kurduğu karşıtlık, günümüz bilinç araştırmaları içerisinde semantik bellek adı verilen zihinsel özellik ile ilişkili olarak ele alınmaktadır. Nesne, renk, parlaklık, yüzey yapısı, şekil, gözlemciye göre uzayda bulunduğu konum ve uzaklık gibi çeşitli fiziksel niteliklere sahiptir (Revonsuo, 2017, s.176). Bu niteliklerin algllanması nesne yoluyla iletilen kavramsal yapıyı anlamak için yeterli değildir. Nesnelerin anlamlı öğeler olarak algılanması için görsel niteliklerin tutarlı bilgi paketleri halinde kavramsal bir haritaya bağlanması gerekmektedir (Revonsuo, 2017, s.177). Yani anlamlılık ölçütü zihin tarafından yerine getirilmektedir. Algılanmış nesnelere anlamlılığı eşleyen zihinsel mekanizma semantik bellek olarak adlandırılmaktadır (Revonsuo, 2017, s.178). Semantik bellek, insanın dünya hakkında sahip olduğu kavramsal ve olgusal bilgiyi içeren uzun süreli belleğin bir parçasıdır. Semantik bellek, algılanan nesneleri anlamlı nesneler olarak tanımamızı mümkün kılmaktadır. Semantik bellekteki nesnelere ait kavramsal kategoriler ortadan kaybolduğunda nesnelerin anlamı da ortadan kaybolmaktadır. Semantik bellekteki kavramsal kategorilerin kaybolmasına semantik bunama denmektedir (Revonsuo, 2017, s.177). Antti Revonsuo'nun belirttiğine göre semantik bunama yaşayan hastalar bir bardak şarabın içine şeker katabilir veya lazanyasının üzerine portakal suyu dökebilir. Bu hastalar zamanla çeşitli nesnelere ait kavramsal bilgilerini kaybetmektedir; ilgili nesne görüldüğünde, hasta o nesneyi tanıyamamakta ve anlamlandıramamaktadır (Revonsuo, 2017, s.178). Semantik bunama adı verilen bu durum, kavramsal sanatta sanat etkinliğinin neden zihinsel bir etkinlik olarak kabul edildiğini açıklığa kavușturmaktadır. Nesnelere ait bilgimiz yalnızca nesnelere ait algılarımız değildir. Semantik bunama yaşayan hastalarda olduğu gibi bir nesne algılanabilir fakat kavramsal kategoriler olmadan anlamlandırılamaz. Nesne, kendisine ait niteliklerden ayrı olarak, bizim ona atadığımız sandalye, masa veya kitap gibi çeşitli fonksiyonları da yerine getirmektedir. Bu fonksiyonların belirlenmesi ve bir nesne için atanması, zihin tarafından her zaman birlikte bulunan duyu verilerinin semantik bellek adı verilen alana kaydedilmesi ile ilişkilidir. Bu durum Bertrand Russell tarafından tümellerin farkına varılması olarak tanımlanmaktadır: sandalye, masa ve kitap gibi kavramlar farkına varılan tümellerin zihinsel karşılığıdır (Russell, 2000, s.49). Dolayısıyla nesnelerin fizikselliği, diğer bir deyișle duyusal anlamda var olan șeyler ile onları yerleştirdiğimiz zihinsel kategoriler, yani düşünsel anlamda var olan şeyler arasında bir ayrım yapılmaktadır. Bu ayrımda dış dünyanın anlamlılığı düşünsel anlamda var olan şeyler üzerinden atanmaktadır. Bu model referans alındığında sanat yapıtı adı verilen gerçekliğin zihinsel bir gerçeklik olarak ele alınması ve Sol LeWitt tarafından nesnenin duyusal olmayan içeriği olarak tanımlanması kaçınılmazdır. Sanat yapıtı, fiziksel bir gerçeklik olarak dış dünyada bulunmamaktadır, o, çeşitli nesneleri anlamlı nesneler olarak kavramamızı sağlayan zihinsel bir haritadır. Semantik bellek adı verilen zihinsel özelliğe bakıldığında insan, kavrama koşulları gereği doğrudan bir dış dünya gerçekliğinin değil, zihni tarafından temsil edilen bir gerçekliğin farkındadır. Bu, dış dünya gerçekliğinin reddini gerektirmese de dış dünyaya ait kılınan gerçekliğin epistemolojik bir gerçeklik olduğunu varsaymak anlamına gelir. Sanat yapıtının ne olduğu veya nerede temsil edildiği meselesi de dolayısıyla fiziksel değil, zihinsel bir problem olarak kabul edilmelidir. Bu problem nihai olarak şöyle tarif edilebilir: dış dünyaya ait deneyimimiz bize çeşitli nesnelerin duyuları sağlamaktadır. Zihin, bu duyulardan gerçek bir öznel deneyim inşa etmektedir. Bu öznel deneyim, herhangi biçimde bir dış gözlemciye açık değildir fakat düalist zihin felsefesi bağlamında değerlendirildiğinde dış dünyanın var olduğu gerçeği kadar tartışmasız bir gerçektir. Çünkü ilk elden ben adı verilen öznel bir deneyimin farkındayızdır ve bu farkındalık düşünen varlık olmak bakımından bir öznel gerçekliğin varlığının ispatıdır. Kavramsal sanat ile birlikte gündeme gelen sanatın zihinsel bir etkinlik olduğu iddiası fizikselliği dışarıda bırakmakta, dolayısıyla öznel deneyim gerçekliğinin temel alınmasına neden olmaktadır. Sanatın öznel deneyim gerçekliğine indirgenmesi veya sanatta öznel gerçekliğin temel alınması nesnelliği dıșarıda bırakmaktadır. Sanatın zihinselliği düşüncesi ile birlikte dış dünya gerçekliğine dayanan bir sanat kavrayışı ortadan kalmaktadır. 


\section{Sonuç}

Araștırma yoluyla ulașılan sonuçların belirtilmesine geçmeden önce şunu belirtmekte yarar vardır. Düalist zihin felsefesi hakkında ifade edilenler Sol LeWitt'in ortaya koyduğu kavramsal sanat kavrayışı ile tutarlıdır. Bu tutarlılık Sol LeWitt'in kavramsal süreçler ile fiziksel gerçeklik arasında yaptığı ayrım ile doğrudan bağlantılıdır. Dolayısıyla düalist zihin felsefesini anlamak belli bir seviyede kavramsal sanat kavrayıșını da anlamaktır. Fakat kavramsal sanatı farklı bir bağlamda ele almak, başka bir deyişle kavramsal sanat hakkında ortaya konan farklı öncülleri referans almak, düalist zihin felsefesinin yapısıyla çelișebilir. Bu çelișme kavramsal sanat hakkında referans alınan argümanların içeriği ile doğrudan ilișkilidir. Bu çalıșmada referans alınan argümanların örtük olarak düalist bir dünya görüşü içerdiği varsayılmakta ve bu varsayım çeşitli akıl yürütmeler ile aydınlatılmaktadır. Bu bağlamda ulaşılan sonuçlar şöyle sıralanabilir:

(1) Kavramsal sanat içerisinde kavramsal süreçler ile fiziksel gerçeklik arasında yapılan ayrım kavramsal süreçlerin fiziksel olmadığı sonucunu doğurmaktadır. Bu bağlamda kavramsal sanat içerisinde fiziksellik sanatın koşulları dışında bırakılmaktadır. Çünkü kavramsal etkinlikler zihinseldir ve zihinsel etkinlikler fiziksel değildir. Kavramlara indirgenen bir sanat yaklaşımı zihinsel olduğundan ve zihinlerin maddi olmayan bir varoluşu olduğundan, sanatın da maddesiz gerçekleștirilebileceği olasılığı gündeme gelmektedir. Sanatın zihinsel bir etkinlik olarak kabul edilmesi ve düşünsel süreçlerin sanat yüklemi taşıdığı düşüncesi, düalist zihin felsefesi bağlamında sanatın herhangi bir fiziksellik içermeden, salt zihinsel bir etkinlik olarak gerçekleştirilebileceği ve bunun sanatın varlığı için yeter kabul edilebileceği sonucunu doğurur.

(2) Sanatın kavramsal süreçler ile ilgili bir etkinlik olarak tasarlanması sanatın kavram ve kavramlar arası ilișkilere indirgenmesi demektir. Kavramlar zihne aittir; kavramsal sanat etkinliği, malzemesi kavramlar olması bakımından ilkece zihinsel bir etkinliktir. Descartes için kavramlar kelimelerin zihinsel karşılıklarıdır. Zihinlerin, ona sahip olan kişiler dışında bir dış gözlemci tarafından gözlemlenememesi kavramların gerçekliğini dış dünya gerçekliğinden koparmaktadır. Kavramsal sanatta sanatın fiziksel yüklemlerden ayrı bir gerçeklik olarak düşünülmesi de temel olarak buraya dayanmaktadır. Kavramsal sanat ile birlikte gündeme gelen sanatın zihinsel bir etkinlik olduğu iddiası fiziksel yüklemleri dışarıda bırakmaktadır. Bu da kavramsal sanat kavrayışı içerisinde sanatın varlığının öznel deneyim gerçekliğine indirgenmesine neden olmaktadır.

(3) Kavramsal sanat ile birlikte gündeme gelen sanatın zihinsel bir etkinlik olduğu iddiası sanatın yapısına yönelik kuşatıcı bir iddia değildir. Sanat, zihinsel bir etkinliktir fakat her zihinsel etkinlik sanat değildir. Dolayısıyla ne türden zihinsel etkinliklerin sanat olduğu belirlenmelidir. Fakat zihinselliğin öznelliği nedeniyle bu probleme bir cevap bulmak oldukça zor görünmektedir.

\section{Kaynakça}

Akdemir, T. ve Köse, E. (2018). Kavramsal sanatın yapısı üzerine bir araştırma. II. Uluslararası sanat araştırmaları sempozyumu bildiri kitabı içinde (s. 324-330). Adana: Çukurova Üniversitesi.

Churchland, P. M. (2012). Madde ve bilinç. (B. Ersöz, Çev.) İstanbul: Alfa Yayınları.

Danto, A. (2012). Siradan olanın başkalaşımı. (E. Berktaș, Ö. Ejder, Çev.) İstanbul: Ayrıntı Yayınları.

Descartes, R. (2015). Duygular ya da ruh halleri. (Ç. Dürüşken, Çev.) İstanbul: Alfa Yayınları.

. (2019a). Meditasyonlar- Metafizik üzerine düşünceler. (Ç. Dürüşken, Çev.) İstanbul: Alfa Yayınları.

(2019b). Yöntem üzerine konuşma. (Ç. Dürüşken, Çev.) İstanbul: Alfa Yayınları.

Edelman, G. ve Tononi, G. (2019). Bilincin evreni: Maddenin hayale dönüşümü. (A. Subaşı, Çev.) İstanbul: Küre Yayınları.

Günday, Ș. (2002). Zihin felsefesi. Bursa: Asa Kitapevi.

Hançerlioğlu, O. (Ed.). (1992). Felsefe ansiklopedisi: Kavramlar ve akımlar. Cilt 1. (2. bs.) İstanbul: Remzi Kitapevi.

LeWitt, S. (1980a). Kavramsal sanat üzerine paragraflar. (Ş. Aysan, N. Damlacı, F. Ulay, Çev.) Sanat olarak betik içinde (s.19-22). İstanbul: Sanat Tanımı Topluluğu Yayımı.

(1980b). Kavramsal sanat üzerine tümceler. (Ş. Aysan, N. Damlacı, F. Ulay, Çev.) Sanat olarak betik içinde (s.23-24). İstanbul: Sanat Tanımı Topluluğu Yayımı. 
Lippard, L. (1997). Six years: The dematerialization of the art object from 1966 to 1972. California: University of California Press.

Özcan, M. (2009). Aristoteles'in varlık görüşü. Kaygı. Uludağ Üniversitesi Fen-Edebiyat Fakültesi Felsefe Dergisi, 13, 113-131.

Priest, S. (2018). Zihin üzerine teoriler. (A. Dereko, Çev.) İstanbul: Litera Yayıncılık.

Revonsuo, A. (2017). Bilinç: Öznelliğin bilimi. (S. Değirmenci, Çev.) İstanbul: Küre Yayınları.

Russell, B. (2000). Felsefe sorunları. (V. Hacıkadiroğlu, Çev.) İstanbul: Kabalcı Yayınları.

Zeman, A. (2017). Bilinç: Kullanım kılavuzu. (G. Koca, Çev.) İstanbul: Metis Yayınları. 